\title{
OPEN WOUNDS OF THE BRAGHIAL PLEXUS
}

\author{
Donal M. BRooks, London, England
}

\author{
From the Institute of Orthopaedics, Royal National Orthopaedic Hospital, London \\ Formerly of the Peripheral Nerve Injuries Unit, Wingfield Morris Orthopaedic Hospital, Oxford
}

Of the peripheral nerve injuries treated at the Wingfield-Morris Orthopaedic Hospital, Oxford, between 1940 and 1945 , it was found that 52 per cent. of the first 1600 cases were due to penetrating wounds. The brachial plexus was damaged in forty-two of these $\mathbf{8 2 0}$ cases, namely, 6 per cent.-a proportion which corresponds closely with that recorded after the first World War by Lehmann (1921) Oppenheim (1923) and Pollock (1926). Isolated high lesions of the median, radial, and ulnar nerves are excluded from this study.

The conspicuous lack of information available in the literature may be due to difficulties of analysis, the intricacy of the plexus, anatomical variations, and the bizarre motor and sensory changes that may occur after injury. Pollock and Davis (1933), and other authors, concentrated on the problem of precise localisation of the lesion rather than on that of functional recovery of the limb. In any given case the damage is seldom uniform and a mixture of neurapraxia, axonotmesis, neurotmesis, and more or less undamaged nerve fibres, is common.

In dealing with degenerative lesions of other peripheral nerves after penetrating wounds there is now little doubt as to the policy that should be adopted; exploration is the rule (Seddon 1948). Does this principle apply to exploration of the brachial plexus? Operations have been described by which the plexus may be exposed throughout its length (Platt 1924, Stiles and Forrester-Brown 1922), but in what proportion of cases is division of nerves likely to be found? Is repair at this level a practical procedure? Are the results of repair such as to justify it?. If the proportion of divisions is small and, still more, if repair at this level is not worth while, is exploration useful only in prognosis? The object of this paper is to answer such questions in the light of experience gained at the Oxford centre during the second world war.

\section{METHODS OF ANALYSIS AND OF REGORDING THE RESULTS OF TREATMENT}

Forty-two cases in which the brachial plexus was damaged by penetrating wounds have been examined. In many of them paralysis was at first complete; but rapid recovery occurred in part of the plexus within a few weeks, leaving residual paralysis which was slow to disappear and from which recovery was often imperfect. All patients were treated by electrical stimulation of the paralysed muscles until voluntary control was restored or until it became evident that no recovery would occur (Jackson 1945). Observations were continued for at least two years after injury and in many cases for three or four years.

In order to compare cases a specific method of grouping, and of grading recovery, has been adopted (Fig. 1):

Group I -Lesions of the roots and trunk of C.5, 6 .

Group II - Lesions of the posterior cord.

Group III-Lesions of C.8, T.1, and the medial cord.

In many cases the lesion involves more than one group; and when injuries involve the whole plexus the grade of recovery is necessarily expressed as a threefold statement.

Paralysis in Group I (deltoid, spinati, biceps, brachialis, brachio-radialis, and extensor carpi radialis longus) causes loss of abduction and external rotation movement at the shoulder joint, and loss of flexion movement at the elbow. Recovery is expressed in terms of ability to perform these movements, muscle power being graded in accord with the

vol. 31 B, NO. 1, FEBRUARY 1949 
system recommended by the Nerve Injuries Committee of the Medical Research Council. The power of abduction is represented thus:

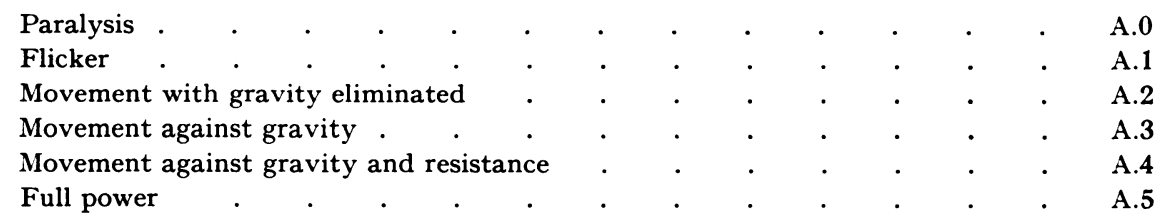

The power of external rotation at the shoulder, and of flexion at the elbow, are expressed similarly, the figures being prefixed by $E$ and $F$ respectively. Sensory recovery after lesions of C.5, 6 is relatively unimportant and will not be discussed.

Paralysis in Group II (the posterior cord) gives rise, for the most part, to loss of power of the deltoid, teres major, latissimus dorsi, subscapularis, triceps, and the forearm extensors. Recovery is expressed thus:

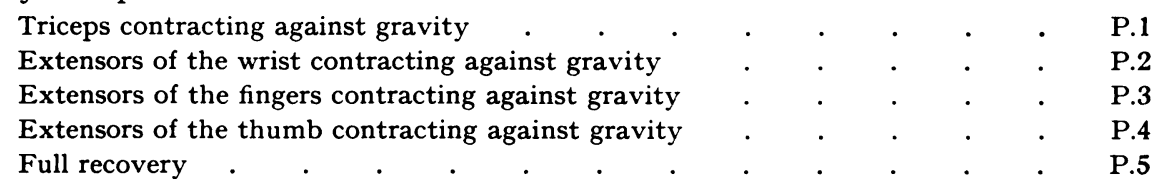

Here again sensory function, being unimportant, is left out of account.

Paralysis in Group III (C.8, T.1, and medial cord)-Recovery is expressed in terms of the distribution of median and ulnar nerves. This method is anatomically inexact in so far as the proximal muscles supplied by the median nerve derive part of their innervation from the lateral cord. Nevertheless, no significant errors could be traced to this compromise, and any attempt to refine the analysis would have made a difficult task almost impossible. The grading is that adopted by the Medical Research Council:

Sensory Recovery

No recovery of sensibility in the autonomous zone of the nerve

S.0

Recovery of deep cutaneous pain sensibility in the autonomous zone of the nerve S.1

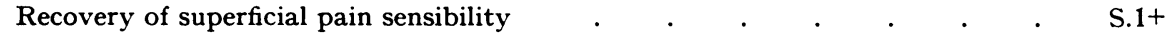

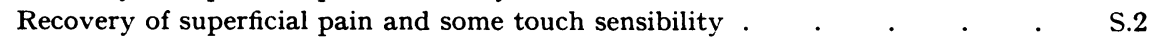

Recovery of superficial pain and touch sensibility but with over-reaction and inability to localise the stimulus . $. \quad . \quad . \quad . \quad . \quad . \quad$.

Recovery of pain and touch sensibility with disappearance of over-reaction or with the appearance of some ability to localise the stimulus . . .

Recovery to S.3 with good localisation \& some recovery of two-point discrimination Complete recovery

Motor Recovery-Median nerve

No contraction .

. M.0

Contraction in the proximal muscles but not against gravity . $\quad . \quad$. $\quad . \quad$ M.1

Proximal muscles acting against gravity; no return of power in thenar muscles . M.1+

Proximal muscles acting against gravity and a flicker in the thenar muscles . M.2

Proximal and thenar muscles acting against resistance . _ . . . . . . M.3

All muscles acting against strong resistance with some independent action $\quad$ • $\quad$ M.4

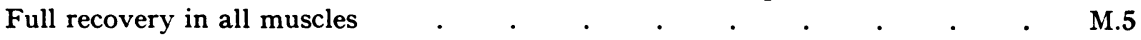

Motor Recovery-Ulnar nerve

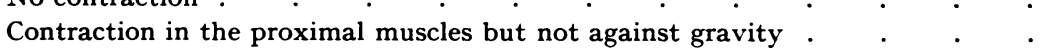

Proximal muscles acting against gravity; no return of power in intrinsic muscles

Proximal muscles acting against gravity, some power in the hypothenars, and little or none in the interossei

Proximal and intrinsic muscles all acting, but the first dorsal interosseous unable to act against resistance

Proximal muscles, hypothenars, \& 1 st dorsal interosseous acting against resistance As in Grade 3 but with some independent lateral movement of fingers . . Full recovery in all muscles 


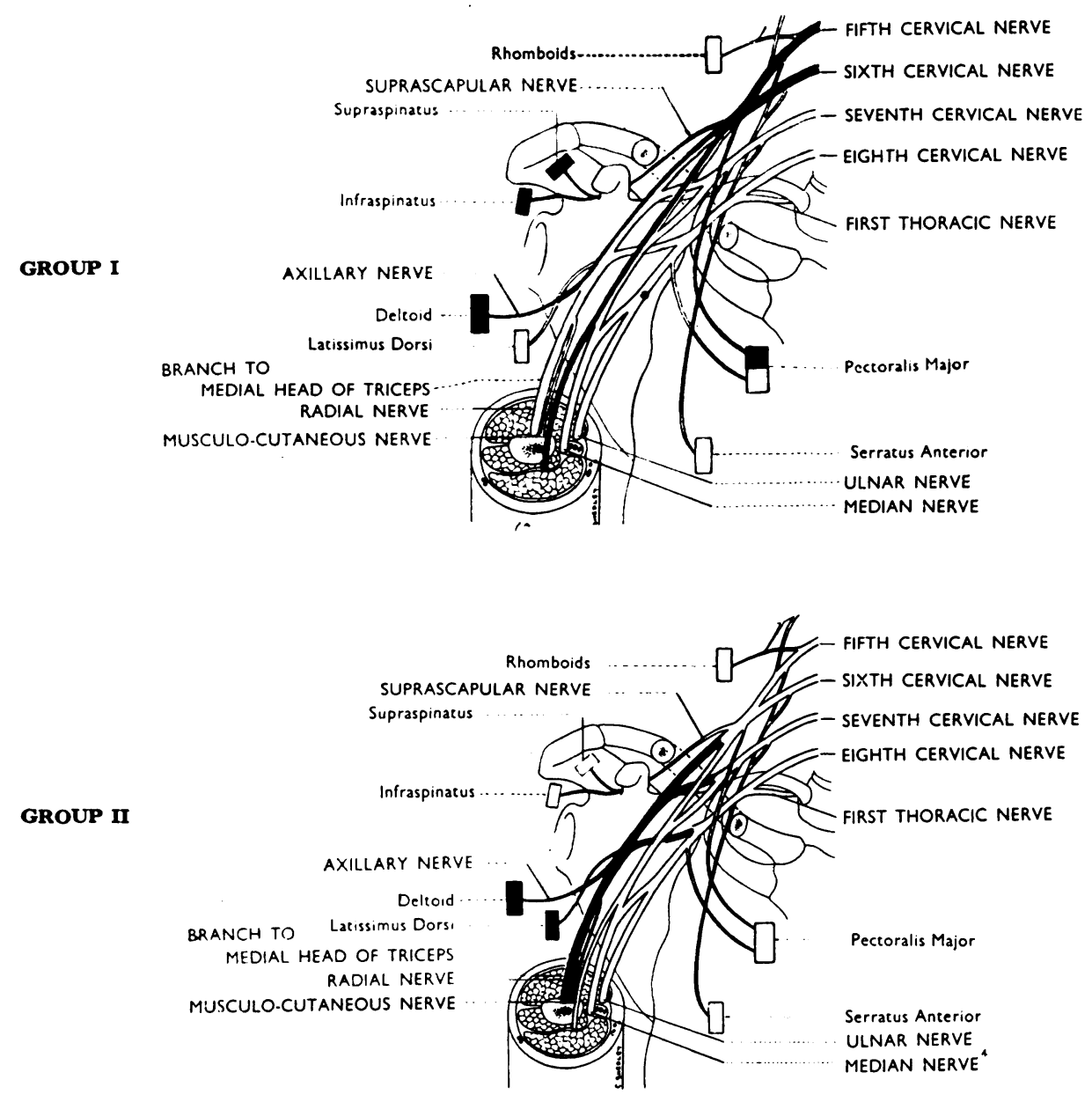

GROUP III

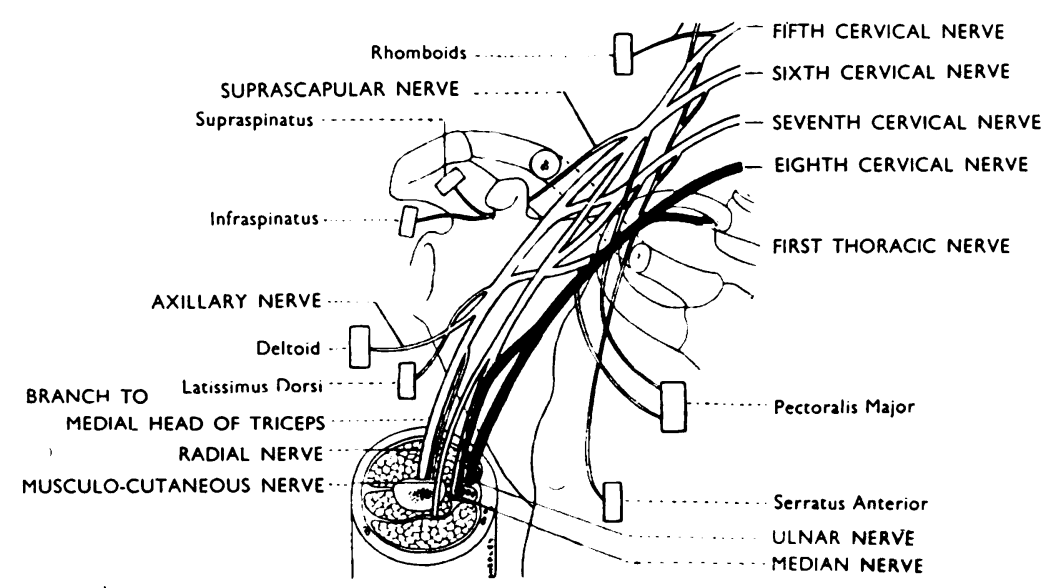

FIG. 1

Diagrams illustrating the three groups of nerve lesions.

(Modified after C. Shepley-Medical Research Council Memorandum on Peripheral Nerve Injuries, 1943.)

VOL. $31 \mathrm{~B}$, NO. 1, FEBRUARY 1949 
TABLE I

Analysis of Recovery in Thirteen Cases with Lesions confined to the ROOTS AND TRUNK OF C.5, 6

\begin{tabular}{|c|c|c|c|c|c|c|c|c|c|c|c|c|c|}
\hline \multirow{2}{*}{$\begin{array}{l}\text { Case } \\
\text { No. }\end{array}$} & \multirow{2}{*}{$\begin{array}{c}\text { Date } \\
\text { of } \\
\text { injury }\end{array}$} & \multirow{2}{*}{$\begin{array}{l}\text { Sensory } \\
\text { loss }\end{array}$} & \multirow{2}{*}{ Explored } & \multicolumn{9}{|c|}{ Time in months from date of injury } & \multirow{2}{*}{$\begin{array}{l}\text { Recon- } \\
\text { structive } \\
\text { surgery }\end{array}$} \\
\hline & & & & & 3 & 6 & 9 & 12 & 15 & 18 & 24 & 36 & \\
\hline B.113 & Aug. '43 & Nune & + & $\begin{array}{l}\mathrm{A} \\
\mathrm{E} \\
\mathrm{F}\end{array}$ & & $\begin{array}{l}0 \\
0 \\
1+\end{array}$ & $\begin{array}{l}1 \\
2+ \\
1+\end{array}$ & $\begin{array}{l}1+ \\
2+ \\
2+\end{array}$ & $\begin{array}{l}2 \\
2 \\
2+\end{array}$ & $\begin{array}{l}2 \\
2 \\
2+\end{array}$ & $\begin{array}{l}2+ \\
2 \\
2+\end{array}$ & 3 & + \\
\hline D.53 & June '44 & C. 4.5 & - & $\begin{array}{l}\mathrm{A} \\
\mathrm{E} \\
\mathrm{F}\end{array}$ & $\begin{array}{l}0 \\
0 \\
0\end{array}$ & $\begin{array}{l}4 \\
3+ \\
4\end{array}$ & $\begin{array}{l}4 \\
3+ \\
4\end{array}$ & $\begin{array}{l}4 \\
4 \\
4\end{array}$ & $\begin{array}{l}4+ \\
4+ \\
4\end{array}$ & & & & - \\
\hline D.63 & Aug. '44 & C. 6 & - & $\begin{array}{l}\mathrm{A} \\
\mathrm{E} \\
\mathrm{F}\end{array}$ & $\begin{array}{l}0 \\
1 \\
2\end{array}$ & $\begin{array}{l}2+ \\
2+ \\
3\end{array}$ & $\begin{array}{l}4 \\
4 \\
3+\end{array}$ & $\begin{array}{l}4 \\
4 \\
4\end{array}$ & $\begin{array}{l}4 \\
4 \\
4\end{array}$ & $\begin{array}{l}4 \\
4 \\
4\end{array}$ & $\begin{array}{l}4 \\
4 \\
4\end{array}$ & & - \\
\hline D. 14 & July '41 & Nune & - & $\begin{array}{l}\mathrm{A} \\
\mathrm{E} \\
\mathrm{F}\end{array}$ & & $\begin{array}{l}0 \\
0 \\
2\end{array}$ & $\begin{array}{l}2 \\
2 \\
3+\end{array}$ & $\begin{array}{l}4 \\
3 \\
4\end{array}$ & $\begin{array}{l}4 \\
3 \\
4+\end{array}$ & $\begin{array}{l}4 \\
3 \\
5\end{array}$ & & & - \\
\hline H.95 & June '44 & C. 5,6 & + & $\begin{array}{l}\mathrm{A} \\
\mathrm{E} \\
\mathrm{F}\end{array}$ & $\begin{array}{l}0 \\
0 \\
2\end{array}$ & $\begin{array}{l}1 \\
0 \\
2+\end{array}$ & $\begin{array}{l}1 \\
0 \\
2+\end{array}$ & $\begin{array}{l}2+ \\
2+ \\
3+\end{array}$ & $\begin{array}{l}\mathbf{4} \\
\mathbf{2}+ \\
\mathbf{4}+\end{array}$ & $\begin{array}{l}4 \\
2+ \\
4+\end{array}$ & $\begin{array}{l}4 \\
2+ \\
4+\end{array}$ & & - \\
\hline H.115 & Sept. '44 & C.5, 6,7 & + & $\begin{array}{l}\mathrm{A} \\
\mathrm{E} \\
\mathrm{F}\end{array}$ & $\begin{array}{l}0 \\
0 \\
0\end{array}$ & $\begin{array}{l}2 \\
0 \\
0\end{array}$ & $\begin{array}{l}2+ \\
1 \\
2\end{array}$ & $\begin{array}{l}3 \\
2 \\
3\end{array}$ & $\begin{array}{l}3^{+} \\
3^{+} \\
3^{+}\end{array}$ & $\begin{array}{l}4 \\
3 \\
4\end{array}$ & & & - \\
\hline K.23 & Jan. '44 & C. 5,6 & + & $\begin{array}{l}\mathrm{A} \\
\mathrm{E} \\
\mathrm{F}\end{array}$ & $\begin{array}{l}0 \\
0 \\
0\end{array}$ & $\begin{array}{l}0 \\
0 \\
1\end{array}$ & $\begin{array}{l}1 \\
0 \\
2\end{array}$ & $\begin{array}{l}2 \\
0 \\
2+\end{array}$ & $\begin{array}{l}3^{+} \\
2 \\
3^{+}\end{array}$ & $\begin{array}{l}3^{+} \\
\mathbf{3} \\
3^{+}\end{array}$ & $\begin{array}{l}4 \\
3 \\
4+\end{array}$ & $\begin{array}{l}4 \\
2 \\
4+\end{array}$ & + \\
\hline L. 62 & Dec. '44 & C.4, 5 & - & $\begin{array}{l}\mathrm{A} \\
\mathrm{E} \\
\mathrm{F}\end{array}$ & $\begin{array}{l}3 \\
3+ \\
4\end{array}$ & $\begin{array}{l}4 \\
4 \\
5\end{array}$ & $\begin{array}{l}4 \\
4 \\
4\end{array}$ & $\begin{array}{l}4 \\
4 \\
4\end{array}$ & $\begin{array}{l}4 \\
4 \\
4\end{array}$ & $\begin{array}{l}4 \\
4 \\
4\end{array}$ & & & - \\
\hline R.36 & Apr. ' 43 & Circumflex & - & $\begin{array}{l}\mathrm{A} \\
\mathrm{E} \\
\mathrm{F}\end{array}$ & $\begin{array}{l}0 \\
0 \\
1\end{array}$ & $\begin{array}{l}0 \\
0 \\
2+\end{array}$ & $\begin{array}{l}1+ \\
1 \\
3\end{array}$ & $\begin{array}{l}2^{+} \\
3^{+}\end{array}$ & $\begin{array}{l}2+ \\
3 \\
3+\end{array}$ & $\begin{array}{l}4+ \\
3 \\
4+\end{array}$ & $\begin{array}{l}\mathbf{4}+ \\
\mathbf{3} \\
4+\end{array}$ & $\begin{array}{l}4^{+} \\
4^{+} \\
4^{+}\end{array}$ & - \\
\hline S.58 & June '42 & Nunc & - & $\begin{array}{l}\mathrm{A} \\
\mathrm{E} \\
\mathrm{F}\end{array}$ & $\begin{array}{l}0 \\
0 \\
3\end{array}$ & $\begin{array}{l}3 \\
3+ \\
3+\end{array}$ & $\begin{array}{l}3 \\
3^{+} \\
3^{+}\end{array}$ & $\begin{array}{l}3 \\
3+ \\
3+\end{array}$ & $\begin{array}{l}4 \\
3+ \\
4\end{array}$ & $\begin{array}{l}4 \\
3+ \\
4\end{array}$ & $\begin{array}{l}4^{+} \\
4 \\
4\end{array}$ & $\begin{array}{l}4^{+} \\
4^{+} \\
4^{+}\end{array}$ & - \\
\hline T.23 & Mar. ' 42 & Nune & - & $\begin{array}{l}\mathrm{A} \\
\mathrm{E} \\
\mathrm{F}\end{array}$ & $\begin{array}{l}2 \\
2 \\
3^{+}\end{array}$ & $\begin{array}{l}4^{+} \\
4 \\
4\end{array}$ & & & & & & & - \\
\hline V.11 & Apr. '44 & C.5, 6 & + & $\begin{array}{l}\mathrm{A} \\
\mathrm{E} \\
\mathrm{F}\end{array}$ & $\begin{array}{l}2 \\
2 \\
2\end{array}$ & $\begin{array}{l}2 \\
2 \\
2\end{array}$ & $\begin{array}{l}4 \\
3 \\
3\end{array}$ & $\begin{array}{l}\mathbf{4} \\
3^{+} \\
3^{+}\end{array}$ & $\begin{array}{l}\mathbf{4}^{+} \\
\mathbf{4}^{+} \\
\mathbf{4}^{+}\end{array}$ & & & & - \\
\hline$Z .23$ & Sept. ' 44 & C.5, 6 & - & $\begin{array}{l}\mathbf{A} \\
\mathbf{E} \\
\mathbf{F}\end{array}$ & $\begin{array}{l}0 \\
0 \\
2\end{array}$ & $\begin{array}{l}3 \\
0 \\
3\end{array}$ & $\begin{array}{l}3+ \\
3+ \\
4\end{array}$ & $\begin{array}{l}4 \\
4 \\
4\end{array}$ & $\begin{array}{l}4 \\
4 \\
4\end{array}$ & $\begin{array}{l}4+ \\
4 \\
5\end{array}$ & $\begin{array}{l}4+ \\
4 \\
5\end{array}$ & $\begin{array}{l}4^{+} \\
4 \\
5\end{array}$ & - \\
\hline
\end{tabular}


Group I (a)-Lesions confined to the roots and trunk of G.5, 6 (Table I)-In thirteen patients the lesion was confined to the roots and trunk of C.5, 6. In only two was there complete motor and sensory paralysis; in eleven there was sparing, more or less, of either motor or sensory function. The good recovery which occurred is shown in Fig. 2. After two years, flexion of the elbow was possible against both gravity and resistance in all cases but one; abduction of the shoulder against gravity was also regained in all cases except this one; and external rotation of the shoulder against gravity was possible in all cases but two. Five operative explorations were made and in none was repair deemed necessary because the nerves were in continuity and it appeared that they were not damaged seriously. In two cases there was a history of wound infection which appeared to have no significant influence on the recovery. With one exception, the final result was good in all cases which showed evidence of motor recovery at nine months from the time of injury.

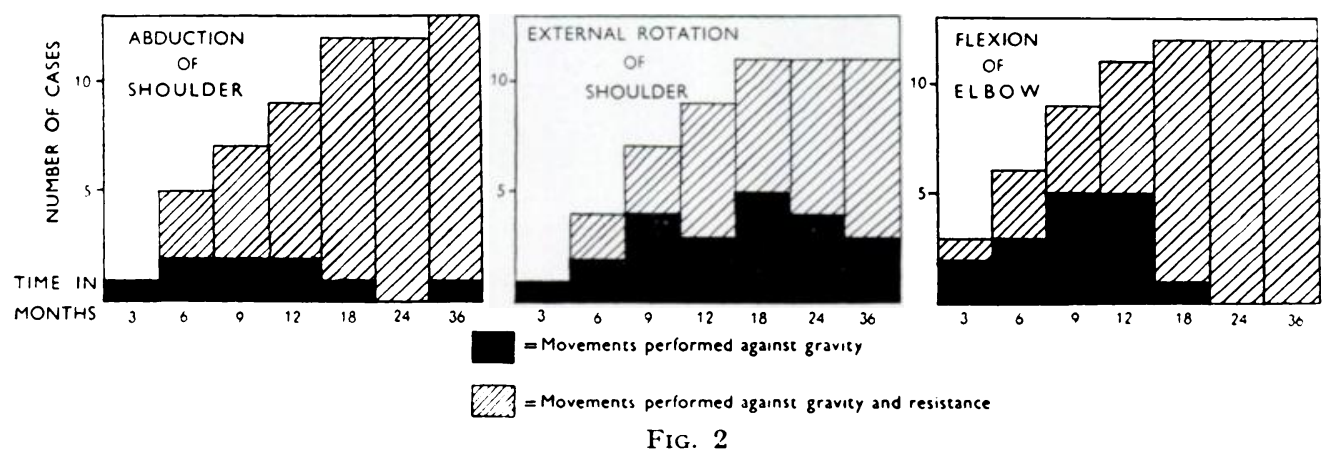

Histogram showing the progress of recovery in thirteen cases in which the lesion was limited to C.5 and 6 .

Group I (b)-The C.5, 6 component in extensive lesions of the plexus (Table II)Analysis of fifteen other cases with more extensive lesions of the plexus showed again that recovery was remarkably good (Fig. 3). Six of these had, at first, complete motor and sensory loss. The others, as in Group I (a), showed some sparing in either motor or sensory function. Nine explorations were made and in only two instances was there division of nerves.

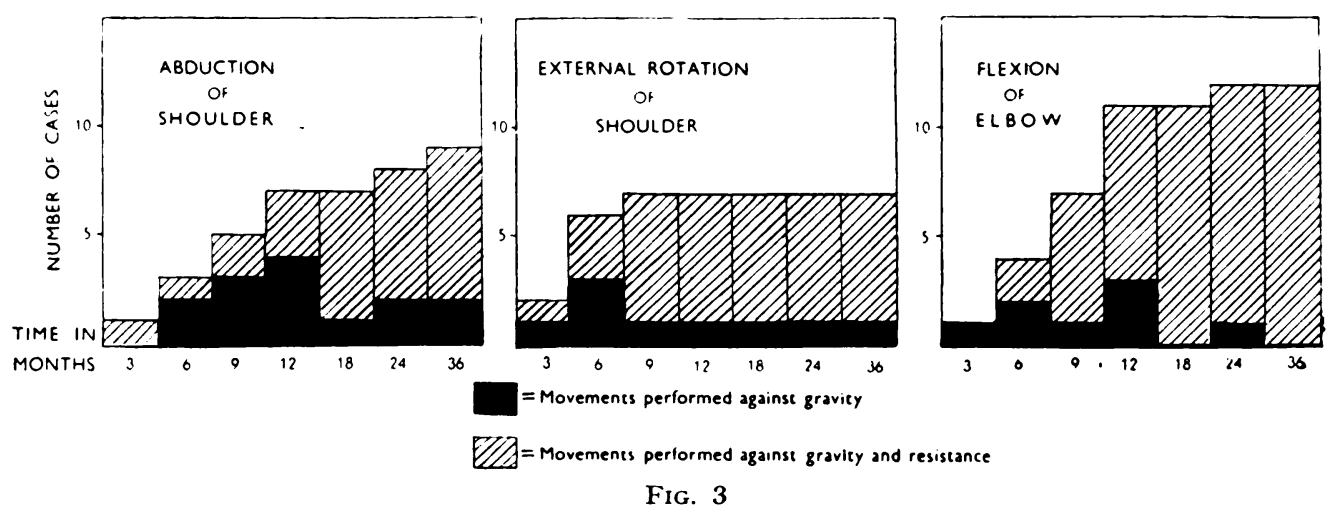

Histogram showing the progress of recovery in the C.5, 6 component in fifteen cases of more extensive lesions of the brachial plexus.

Group II-Lesions of the posterior cord (Table III) - There were twenty-one patients with injury of the posterior cord of the plexus, but only in one was there no other damage. This man was first seen two years after injury and he was kept under observation for one year more, by which time there was recovery only in the triceps. In twenty patients the injury

vol. 31 B, No. 1, FEBRUARY 1949

BI 
TABLE II

Analysis of Recovery of the C.5, 6 component in Fifteen Cases of Extensive Lesions of the Plexus

\begin{tabular}{|c|c|c|c|c|c|c|c|c|c|c|c|c|c|c|}
\hline \multirow{2}{*}{$\begin{array}{l}\text { Case } \\
\text { No. }\end{array}$} & \multirow{2}{*}{$\begin{array}{c}\text { Date } \\
\text { of } \\
\text { injury }\end{array}$} & \multirow{2}{*}{$\begin{array}{c}\text { Sensory } \\
\text { loss }\end{array}$} & \multirow{2}{*}{ 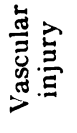 } & \multirow{2}{*}{ 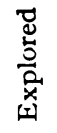 } & \multicolumn{9}{|c|}{ Time in months from date of injury } & \multirow{2}{*}{$\begin{array}{l}\text { Recon- } \\
\text { structive } \\
\text { surgery }\end{array}$} \\
\hline & & & & & & 3 & 6 & 9 & 12 & 15 & 18 & 24 & 36 & \\
\hline B. 164 & Aug. '44 & None & - & - & $\begin{array}{l}\mathrm{A} \\
\mathrm{E} \\
\mathrm{F}\end{array}$ & $\begin{array}{l}0 \\
0 \\
2\end{array}$ & $\begin{array}{l}2 \\
3 \\
4\end{array}$ & $\begin{array}{l}3 \\
4 \\
4+\end{array}$ & & & & & & - \\
\hline B. 195 & Mar. '45 & $\begin{array}{l}\text { Com- } \\
\text { plete } \\
\text { plexus }\end{array}$ & - & + & $\begin{array}{l}\mathrm{A} \\
\mathrm{E} \\
\mathrm{F}\end{array}$ & $\begin{array}{l}0 \\
0 \\
0\end{array}$ & $\begin{array}{l}0 \\
0 \\
1\end{array}$ & $\begin{array}{l}2 \\
0 \\
2+\end{array}$ & $\begin{array}{l}3+ \\
2 \\
4\end{array}$ & $\begin{array}{l}4 \\
2 \\
4\end{array}$ & $\begin{array}{l}4 \\
2 \\
4\end{array}$ & $\begin{array}{l}4+ \\
\frac{4}{4} \\
4+\end{array}$ & & - \\
\hline B.171 & Sept. ' 44 & C.7 & - & + & $\begin{array}{l}\mathrm{A} \\
\mathrm{E} \\
\mathrm{F}\end{array}$ & $\begin{array}{l}4+ \\
5 \\
0\end{array}$ & $\begin{array}{l}4+ \\
5 \\
0\end{array}$ & $\begin{array}{l}4+ \\
5 \\
1\end{array}$ & $\begin{array}{l}\mathbf{4}^{+} \\
\mathbf{5} \\
\mathbf{3}\end{array}$ & $\begin{array}{l}4+ \\
5 \\
4\end{array}$ & $\begin{array}{l}4^{+} \\
5 \\
4\end{array}$ & & & - \\
\hline C.134 & Oct. ' 44 & C.5, 6 & - & - & $\begin{array}{l}\mathrm{A} \\
\mathrm{E} \\
\mathrm{F}\end{array}$ & $\begin{array}{l}0 \\
0 \\
2\end{array}$ & $\begin{array}{l}1 \\
0 \\
3\end{array}$ & $\begin{array}{l}2 \\
2 \\
4\end{array}$ & $\begin{array}{l}3 \\
2 \\
4\end{array}$ & $\begin{array}{l}3^{+} \\
\mathbf{2} \\
4^{+}\end{array}$ & $\begin{array}{l}4 \\
2 \\
4\end{array}$ & & & + \\
\hline H. 107 & May '44 & $\begin{array}{l}\text { Below } \\
\text { elbow }\end{array}$ & - & - & $\begin{array}{l}\mathrm{A} \\
\mathrm{E} \\
\mathrm{F}\end{array}$ & $\begin{array}{l}2+ \\
2 \\
3\end{array}$ & $\begin{array}{l}3+ \\
3 \\
4\end{array}$ & $\begin{array}{l}3+ \\
3 \\
4\end{array}$ & $\begin{array}{l}3^{+} \\
3 \\
4\end{array}$ & $\begin{array}{l}4 \\
3 \\
4\end{array}$ & & & & - \\
\hline K.7 & June '41 & C.5, 6,7 & + & + & $\begin{array}{l}\mathrm{A} \\
\mathrm{E} \\
\mathrm{F}\end{array}$ & $\begin{array}{l}0 \\
0 \\
0\end{array}$ & $\begin{array}{l}0 \\
3 \\
2\end{array}$ & $\begin{array}{l}3 \\
4 \\
4\end{array}$ & $\begin{array}{l}4^{+} \\
4 \\
5\end{array}$ & & & & & - \\
\hline K.8 & July '41 & C.5, 6,7 & - & + & $\begin{array}{l}\mathrm{A} \\
\mathrm{E} \\
\mathrm{F}\end{array}$ & & & & $\begin{array}{l}0 \\
0 \\
0\end{array}$ & $\begin{array}{l}1 \\
0 \\
0\end{array}$ & $\begin{array}{l}1+ \\
0 \\
0\end{array}$ & $\begin{array}{l}2 \\
0 \\
0\end{array}$ & $\begin{array}{l}2+ \\
0 \\
0\end{array}$ & - \\
\hline L.43 & Oct. ' 43 & $\begin{array}{l}\text { C.8 } \\
\text { T.1 }\end{array}$ & + & - & $\begin{array}{l}\mathrm{A} \\
\mathbf{E} \\
\mathbf{F}\end{array}$ & & $\begin{array}{l}3 \\
5 \\
3\end{array}$ & $\begin{array}{l}4+ \\
5 \\
4\end{array}$ & & & & & & + \\
\hline M.101 & Sept. '44 & C.5, 6 & + & + & $\begin{array}{l}\mathrm{A} \\
\mathrm{E} \\
\mathrm{F}\end{array}$ & & $\begin{array}{l}0 \\
4 \\
2\end{array}$ & $\begin{array}{l}1 \\
4 \\
4\end{array}$ & $\begin{array}{l}1 \\
4 \\
4\end{array}$ & $\begin{array}{l}1 \\
4 \\
4\end{array}$ & $\begin{array}{l}2+ \\
4 \\
4+\end{array}$ & $\begin{array}{l}4 \\
4 \\
5\end{array}$ & & + \\
\hline P.38 & Jan. '43 & $\begin{array}{l}\text { Com- } \\
\text { plete } \\
\text { plexus }\end{array}$ & - & - & $\begin{array}{l}\mathrm{A} \\
\mathrm{E} \\
\mathrm{F}\end{array}$ & & $\begin{array}{l}0 \\
0 \\
0\end{array}$ & $\begin{array}{l}\mathbf{0} \\
\mathbf{0} \\
\mathbf{0}\end{array}$ & $\begin{array}{l}0 \\
0 \\
0\end{array}$ & $\begin{array}{l}1 \\
1 \\
1\end{array}$ & $\begin{array}{l}2 \\
1 \\
1\end{array}$ & $\begin{array}{l}2+ \\
2 \\
2\end{array}$ & $\begin{array}{l}3^{+} \\
2 \\
2\end{array}$ & - \\
\hline P.59 & Sept. '43 & C.5, 6 & - & + & $\begin{array}{l}\mathrm{A} \\
\mathrm{E} \\
\mathrm{F}\end{array}$ & $\begin{array}{l}\mathbf{0} \\
3+ \\
0\end{array}$ & $\begin{array}{l}0 \\
3+ \\
1\end{array}$ & $\begin{array}{l}0 \\
4 \\
3+\end{array}$ & $\begin{array}{l}0 \\
5 \\
4\end{array}$ & $\begin{array}{l}0 \\
5 \\
4\end{array}$ & $\begin{array}{l}0 \\
5 \\
4\end{array}$ & $\begin{array}{l}0 \\
5 \\
4\end{array}$ & $\begin{array}{l}0 \\
5 \\
4\end{array}$ & - \\
\hline S.158 & Feb. ' 45 & C.4, 5, 6 & - & + & $\begin{array}{l}\mathrm{A} \\
\mathrm{E} \\
\mathrm{F}\end{array}$ & $\begin{array}{l}0 \\
0 \\
0\end{array}$ & $\begin{array}{l}2 \\
0 \\
0\end{array}$ & $\begin{array}{l}2+ \\
0 \\
2\end{array}$ & $\begin{array}{l}2+ \\
0 \\
3+\end{array}$ & $\begin{array}{l}2+ \\
0 \\
0\end{array}$ & $\begin{array}{l}2+ \\
0 \\
4\end{array}$ & $\begin{array}{l}2+ \\
0 \\
4\end{array}$ & & + \\
\hline S.143 & June '44 & C.5 & + & - & $\begin{array}{l}\mathrm{A} \\
\mathrm{E} \\
\mathrm{F}\end{array}$ & $\begin{array}{l}0 \\
0 \\
0\end{array}$ & $\begin{array}{l}0 \\
0 \\
0\end{array}$ & $\begin{array}{l}0 \\
0 \\
0\end{array}$ & $\begin{array}{l}\mathbf{0} \\
0 \\
0\end{array}$ & $\begin{array}{l}0 \\
0 \\
1\end{array}$ & $\begin{array}{l}0 \\
0 \\
1+\end{array}$ & $\begin{array}{l}0 \\
0 \\
3\end{array}$ & $\begin{array}{l}0 \\
0 \\
4\end{array}$ & - \\
\hline W.102 & June '44 & $\begin{array}{l}\text { Com- } \\
\text { plete } \\
\text { plexus }\end{array}$ & + & + & $\begin{array}{l}\mathrm{A} \\
\mathrm{E} \\
\mathrm{F}\end{array}$ & $\begin{array}{l}0 \\
0 \\
0\end{array}$ & $\begin{array}{l}\mathbf{0} \\
\mathbf{0} \\
\mathbf{0}\end{array}$ & $\begin{array}{l}1+ \\
0 \\
2+\end{array}$ & $\begin{array}{l}\mathbf{2} \\
0 \\
3^{+}\end{array}$ & $\begin{array}{l}2 \\
0 \\
4\end{array}$ & $\begin{array}{l}2 \\
0 \\
4\end{array}$ & $\begin{array}{l}2 \\
0 \\
4\end{array}$ & & + \\
\hline H.113 & June '44 & C. $5,6,7$ & - & + & $\begin{array}{l}\mathrm{A} \\
\mathrm{E} \\
\mathrm{F}\end{array}$ & $\begin{array}{l}\mathbf{0} \\
0 \\
0\end{array}$ & $\begin{array}{l}0 \\
0 \\
0\end{array}$ & $\begin{array}{l}0 \\
0 \\
0\end{array}$ & $\begin{array}{l}2 \\
0 \\
2\end{array}$ & $\begin{array}{l}2+ \\
0 \\
3\end{array}$ & $\begin{array}{l}2+ \\
2 \\
3^{+}\end{array}$ & $\begin{array}{l}3 \\
2 \\
4\end{array}$ & $\begin{array}{l}4 \\
2 \\
4\end{array}$ & - \\
\hline
\end{tabular}


also involved the medial cord, or the whole of the remainder of the plexus, in roughly equal proportions. The behaviour of the posterior cord was much the same in all, and no separate analysis is necessary. Over half of these twenty cases reached Grade 4 within two years of the date of injury; that is to say there was ability to extend the thumb against gravity. Almost three-quarters of them reached Grade 3 (Fig. 4). Where there was no evidence of recovery in the triceps within nine months of injury the prognosis was usually poor; and it was always so if there was no recovery within a year. Patients who were kept under observation for more than two years showed no significant change.

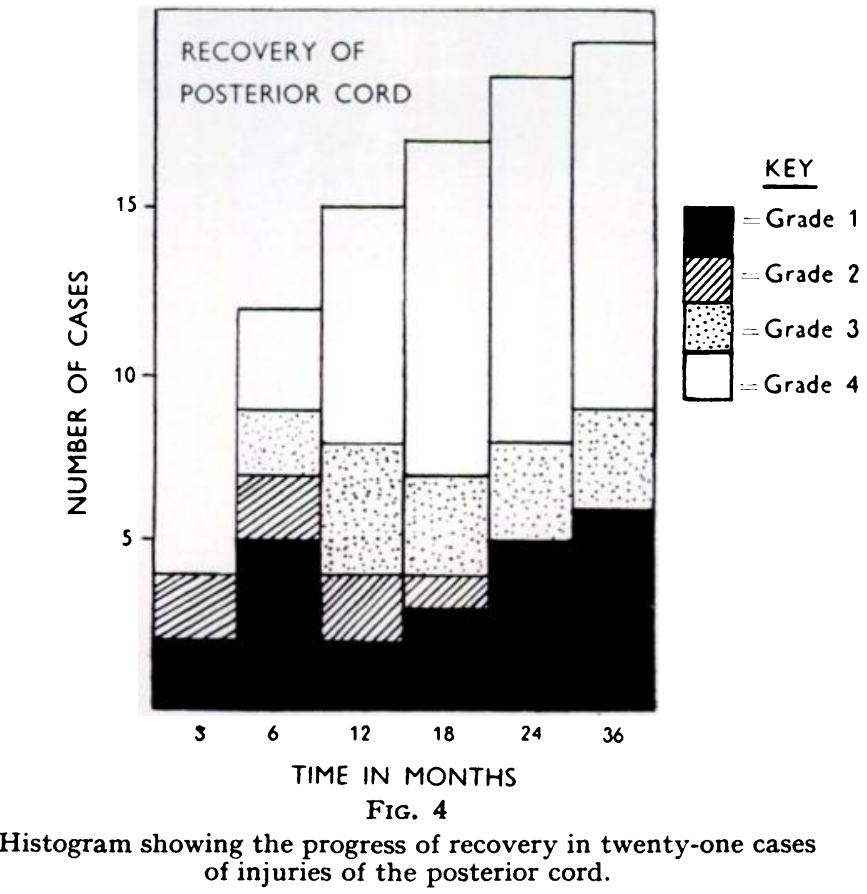

Group III-Lesions of C.8, T.1, and medial cord (Table IV)-Twenty-five cases are considered in this group. This number included eleven in which the whole plexus was involved: five in which the lesion was confined to the medial cord, six in which the posterior and medial cords were affected, and three in which the upper trunk and medial cord were damaged. The progress of recovery in these subdivisions showed no significant differences. When there was complete motor paralysis at six months in either the median or ulnar nerve distributions (axonotmesis or neurotmesis of the relevant segment), and no evidence of motor recovery in the proximal muscles by one year, the outlook was very poor. The best recovery after axonotmesis was seen in case K.5 : after two years, recovery was M.4, S.3, in the median nerve distribution. This case is of special interest: median paralysis occurred after the development of a traumatic aneurism of the axillary artery; when the plexus was explored four months after injury no macroscopic lesion of the medial cord or of its branches could be detected; in other words, the lesion must have been a pure axonotmesis due to compression by the aneurism. This case was the only one in which material recovery took place in the distal muscles after a complete degenerative lesion, presumably because none of the fibres had suffered such permanent damage as almost always occurs after penetrating wounds. In those cases in which it was possible to continue observations for a longer period there was no significant improvement in motor function between the second and third years, but in some the quality of sensibility continued to improve up to four years from the time of injury. Sensory sparing does not carry with it a guarantee of adequate motor recovery, a finding that was emphasized by Pollock (1926) and which has been confirmed repeatedly in this series.

VOL. $31 \mathrm{~B}$, NO. 1, FEBRUARY 1949 
TABLE III

Analysis of Reconery in Twenty-one Cases of Lesions of the Posterior Cord

\begin{tabular}{|c|c|c|c|c|c|c|c|c|c|c|c|}
\hline \multirow{2}{*}{$\begin{array}{l}\text { Case } \\
\text { No. }\end{array}$} & \multirow{2}{*}{$\begin{array}{l}\text { Date of } \\
\text { injury }\end{array}$} & \multirow{2}{*}{$\begin{array}{l}\text { Sensory } \\
\text { loss }\end{array}$} & \multirow{2}{*}{$\begin{array}{l}\text { Vascular } \\
\text { injury }\end{array}$} & \multirow{2}{*}{ Explored } & \multicolumn{6}{|c|}{$\begin{array}{l}\text { Time in months from date } \\
\text { of injury }\end{array}$} & \multirow{2}{*}{$\begin{array}{l}\text { Recon- } \\
\text { structive } \\
\text { surgery }\end{array}$} \\
\hline & & & & & 3 & 6 & 12 & 18 & 24 & 36 & \\
\hline B. 164 & Aug. ' 44 & None & - & - & 1 & 5 & & & & & - \\
\hline B.132 & Nov. '42 & None & - & - & & & & & 1 & 1 & - \\
\hline B. 195 & Mar. '45 & $\begin{array}{l}\text { Complete } \\
\text { plexus }\end{array}$ & - & + & 0 & 0 & 0 & 0 & 1 & 1 & - \\
\hline C.134 & Oct. ' 44 & C.5, 6 & - & - & 1 & 1 & 2 & 4 & 4 & 4 & + \\
\hline F.47 & Feb. '44 & $\begin{array}{c}\text { Ulnar } \\
\text { distribution }\end{array}$ & + & + & 0 & 1 & 4 & 5 & & & - \\
\hline H.113 & June '44 & C. $5,6,7$ & - & + & 0 & 0 & o & 0 & 0 & 1 & - \\
\hline H.36 & Aug. '42 & $\begin{array}{c}\text { Radial and } \\
\text { ulnar } \\
\text { distribution }\end{array}$ & + & + & 0 & 2 & 3 & 3 & 3 & 3 & - \\
\hline H.2 & Nov. ' 40 & C. 8, T.1 & - & + & 2 & 3 & 4 & 4 & 4 & & - \\
\hline K.7 & June '41 & C. $5,6,7$ & + & + & 2 & 3 & 4 & & & & - \\
\hline K.8 & July '41 & C. $5,6,7$ & - & + & $\mathbf{0}$ & $\mathbf{0}$ & 0 & 1 & 1 & 1 & - \\
\hline L. 65 & Feb. '45 & C. 5,6 & + & + & 0 & 1 & 3 & 4 & 4 & & - \\
\hline L.43 & Oct. ' 43 & $\begin{array}{l}\text { Almost } \\
\text { complete } \\
\text { plexus }\end{array}$ & + & - & 0 & 0 & 3 & 4 & 4 & 4 & + \\
\hline Mc. 24 & June '44 & None & - & - & 0 & 4 & 5 & & & & - \\
\hline M.26 & June '44 & $\begin{array}{l}\text { Complete } \\
\text { plexus }\end{array}$ & + & + & 0 & 1 & 3 & 3 & & & - \\
\hline M.101 & July '44 & C.5, 6 & + & + & 0 & 0 & 1 & 1 & 1 & 1 & + \\
\hline P.47 & Jan. '43 & $\begin{array}{l}\text { Sparing } \\
\text { posterior } \\
\text { cord only }\end{array}$ & + & + & & 3 & 4 & 4 & 4 & 4 & - \\
\hline P.38 & Jan. ' 43 & $\begin{array}{l}\text { Complete } \\
\text { plexus }\end{array}$ & - & - & 0 & 0 & 0 & 0 & 0 & 0 & - \\
\hline P.59 & Sept. '43 & $\begin{array}{c}\text { C.5, } 6 \\
\text { complete. } \\
\text { C.7, 8. T.1 } \\
\text { incomplete }\end{array}$ & - & + & 0 & 0 & 1 & 2 & 3 & 3 & - \\
\hline S. 158 & Feb. ' 45 & C. $4,5,6$ & - & + & 0 & 4 & 5 & & & & + \\
\hline S.104 & Aug. ' 43 & C.8, T.1 & - & + & & 2 & 2 & 3 & 4 & 4 & - \\
\hline W.102 & June '44 & $\begin{array}{l}\text { Complete } \\
\text { plexus }\end{array}$ & + & + & 0 & 0 & 0 & 1 & 1 & 1 & + \\
\hline
\end{tabular}




\section{EXPLORATION OF THE PLEXUS}

In twenty-two patients operative exploration of the plexus was undertaken because there was: a severe lesion involving the whole plexus; a complete lesion of a localised part of the plexus such as the upper trunk; or persistent pain in the limb (Table V). In no case was it considered justifiable to resect a lesion in continuity; and in only four was a nerve found to be divided, repair being possible in three. There was an average delay of six months between the time of injury and operation, the earliest exploration being at one month, and the latest at thirteen months. At the time of exploration incidental " neurolysis" was of course inevitable but there was no substantial evidence that recovery was influenced by such neurolysis, though in one case it did relieve persistent pain in the limb. In general, scarring was severe and it was not always possible, or at any rate safe, to expose the entire plexus. For this reason, nerve trunks which were actually seen are specified in the accompanying table. The most severe scarring was seen in two cases in which there were aneurisms of the axillary artery, and both made good recoveries.

Types of lesion-Exploration of the nerves showed: 1) no obvious change; 2 ) " degenerative appearance" of the nerve-a grey-pink translucent appearance which is characteristic and may be due to the disappearance of myelin (when no neuroma was found this appearance was presumed to indicate axonotmesis); 3) nerve enveloped in scar tissue, with or without evidence of constriction; 4) neuroma-(a) fusiform, hard or soft; (b) lateral; 5) interruption of continuity. Intraneural scarring was never found by itself; in every case it was seen in association with a neuroma.

Correlation of operative findings with recovery observed after two years from the time of injury-1) No obvious damage-On eight occasions the part of the plexus exposed showed no evidence of abnormality; yet in only half these cases was recovery good. In one instance, however, it is likely that the lesion was distal to the field of exploration.

2) Degenerative appearance of the nerve-In four cases part of the plexus showed degenerative changes, and in two there was proximal thickening of the nerve without neuroma formation. These were presumed to be examples of axonotmesis, and the favourable prognosis which was given was justified subsequently in so far as re-innervation of the proximal muscles was concerned. Nevertheless recovery in the distal muscles was consistently poor and it was never of functional significance.

3) Enveloping scar-Where extensive scarring surrounded part of the plexus, and there was no other evidence of injury, recovery was good except in one case where a vascular lesion caused ischaemic damage of nerves and muscles.

4) Neuromata-a) Fusiform neuroma-On two occasions a fusiform neuroma was seen and there was good recovery in the affected segment of the plexus. In two cases where a hard neuroma was found, one on the posterior cord and the other on the root of C.7, recovery was very poor. In one case there were three soft neuromata, on the posterior and lateral cords and on the lateral root of median, and fair recovery took place in each segment. b) Lateral neuroma-In four cases a lateral neuroma was discovered. In two, recovery was poor; on the other hand recovery was good in one case in which the neuroma appeared to involve two-thirds of the nerve.

5) Neurotmesis - In only four cases was there interruption of continuity. Repair was possible in three. In one, the upper trunk was divided; suture was performed and, after two years, recovery of flexion at the elbow against gravity and resistance was possible but abduction and external rotation of the shoulder were weak. In the second case, branches of the upper trunk were found to be divided. After resection of proximal and distal stumps it was impossible to restore continuity by direct suture, and three grafts were taken from the medial cutaneous nerve of the forearm as it traversed the upper arm; no certain evidence of regeneration through the grafts was found three years after operation. In the third case, the inner and outer heads of the median nerve were divided. After resection, the gap measured

vol. $31 \mathrm{~B}$, No. 1, FEBRUARY 1949 
six centimetres and suture was possible only after mobilisation of the median nerve as far distally as the cubital fossa, with sacrifice of the branches to pronator teres; recovery in the median area at three years was M.1, S.2+. In the last case, the lateral cord was divided together with the medial head of median nerve. In searching for the peripheral stump of the median nerve it proved necessary to extend the dissection fifteen centimetres below the coracoid process. There was no obvious explanation for this wide gap unless possibly the nerve trunk had been removed inadvertently at the time of the original wound excision (though it is to be noted that Scaglietti (1942) suggests that excessive retraction of the distal stump may occur in consequence of the weight of the limb when part of the plexus is divided).

\section{DISCUSSION}

The most striking feature of these explorations has been the comparatively few occasions on which there has been division of nerve tissue-no more than four instances in a series of twenty-two operations. This is in sharp contrast with the degenerative nerve lesions which occur more distally in open wounds, where experience has shown that one in every two cases is associated with nerve division (Seddon 1948).

Closure of the gap after resection is not easy. In only one case, with injury of the upper trunk, was such closure possible without extensive mobilisation of the distal stump. In a second case a nerve graft was used; and in a third, mobilisation of the median nerve as far as the elbow joint was necessary. In all three of these cases the degree of recovery was discouraging.

As in other nerve injuries at a high level-for example, proximal injuries of the sciatic nerve-if there is to be good functional recovery, early repair is imperative. Ferron (1919), reporting operative findings in two early explorations of the plexus, remarked "que les symptômes paralytiques ne sont pas toujours en rapport avec lés lesions macroscopiques constatées lors de l'opération." This compares unfavourably with the relatively accurate correlation between operative findings and prognosis in other nerves (Seddon 1943, 1948), and our experience of early and late explorations is much the same. In every case the plexus was stimulated electrically and, if this showed conduction in part of the nerve, no more was done. Unfortunately such stimulation gives little information as to the exact pathology of a nerve lesion, and in early explorations negative findings are valueless. Thus axonotmesis, and severe intraneural scarring amounting to neurotmesis, cannot be distinguished. Trial section, a valuable aid in more distal lesions, is technically difficult on account of lack of mobility of the plexus and the consequent difficulty in inspecting a small transected area. Moreover, there is reason to believe that naked-eye appearances of nerve sections at this level are less reliable than elsewhere. Ancillary methods, which are usually so valuable in deciding for or against resection of a neuroma, are therefore of little application in this region where they are most needed.

From these exacting and time-consuming operations the dismal conclusion must be reached that a reliable prognosis cannot be given except in those few cases where a nerve trunk is found to be divided, or where there is a hard neuroma-an indication that the greater part of the nerve is blocked permanently. In axonotmesis, the conditions for recovery are the best possible: the stroma of nerve is preserved to a large extent; and the outgrowing axons remain in their appropriate Schwann tubes. Recovery then depends only on the distance between the lesion and the periphery: it is no more than a matter of time. In the upper trunk, and in the posterior cord, the distance from the site of damage to the denervated muscles is relatively short; but in the medial cord the distance to the muscles of the hand is much greater. Is delay, even in axonotmesis, an adverse factor? Apparently it is, for recovery in Groups I and II was consistently better than in Group III.

The harmful influence of delay on the recovery of motor function is due to shrinkage of the empty Schwann tubes, atrophy of muscle fibres, interstitial fibrosis, and disappearance 
of motor end-plates (Holmes and Young 1942, Gutmann and Young 1944, Bowden and Gutmann 1944). It is possible, though not clearly established, that the effect on sensory regeneration may be similar. It was shown, however, by Simpson and Young (1945) that the small size of Schwann tubes at the periphery may be less significant than was at first believed, and it has been assumed increasingly that muscle atrophy was the more important factor. Gutmann and Guttmann (1942) proved that, in the rabbit, regular intensive galvanic stimulation could be relied upon to a remarkable degree in preventing atrophy of denervated muscle and maintaining its normal state as determined histologically. That such treatment is valuable in clinical practice, particularly in the small muscles of the hand, has also been demonstrated by Jackson (1945). Useful return of power in the intrinsic muscles of the hand might therefore be expected in proximal nerve lesions in which there was prospect of spontaneous recovery, and in which fair recovery did in fact take place in the proximal muscles, provided only that wasting was prevented by regular and adequate galvanic stimulation. The fact is, however, that although such treatment is consistently effective in lesions of the ulnar nerve, recovery of function in the small muscles of the hand after injuries of the brachial plexus did not occur except in one case where the rate of regeneration was exceptionally rapid. We must conclude that shrinkage of Schwann tubes is significant after all, or that the beneficial effects of galvanic stimulation are of limited duration.

Results of exploration in C.5, 6 lesions (Groups Ia, Ib)-Good recovery occurred regularly in both divisions of this group. In over half the cases, recovery in the biceps preceded that in the deltoid and the external rotators of the shoulder, and on several occasions some action in the biceps was maintained where motor paralysis was otherwise complete. Moreover, when motor power became stationary, flexion of the elbow was often the most powerful movement of the three. This suggests that innervation of the biceps may not always be limited to C.5 and 6-a possibility which gains further support from certain observations: 1) On exploration of an extensive lesion of the plexus, with sparing of the deltoid and spinati, the upper trunk was found to be intact, but the root of C.7 was damaged to the extent of one-third of its diameter; the biceps only was paralysed. 2) In another case the upper trunk was found to be divided but an apparently intact branch from C.7 joined the distal stump: the upper trunk was repaired; recovery in the biceps preceded that in the deltoid and spinati ; and, three years after injury, flexion of the elbow was possible against gravity and resistance whereas there was only slight power in the deltoid and no recovery in the external rotators. 3) A third case, operated on elsewhere for a surgical condition in the neck, suffered accidental division of the upper trunk which was sutured immediately; action in the biceps against gravity was never lost. Thus recovery of the biceps after lesions involving the upper trunk may not necessarily indicate axonal regeneration in the C.5 and 6 component, and may account in some measure for the comparatively favourable reputation which suture of the upper trunk has enjoyed. Similarly, the good recovery that usually occurs in lesions in continuity of C.5, 6 does not necessarily prove that a conservative attitude is wholly justified.

Results in posterior cord lesions (Group II) - On the whole, recovery in this group was good. As in Group I, there are, relatively speaking, no distal muscles to be re-innervated and the length of axonal regeneration is not unduly great.

Results in lesions of C.8, T.1, and the medial cord (Group III)-In cases showing complete degenerative lesions, functional recovery was disappointing. The distal muscles never regained useful action; occasionally a flicker of contraction or evidence of electromyographic activity showed that some axonal regeneration had taken place, but unfortunately not before secondary changes in the muscles or nerves had prejudiced recovery. Even in the presence of reasonably powerful proximal muscles, use of the hand was severely limited, and impaired sensibility was a serious disadvantage. In spite of treatment continued for more

VOL. $31 \mathrm{~B}$, NO. 1, FEBRUARY 1949 


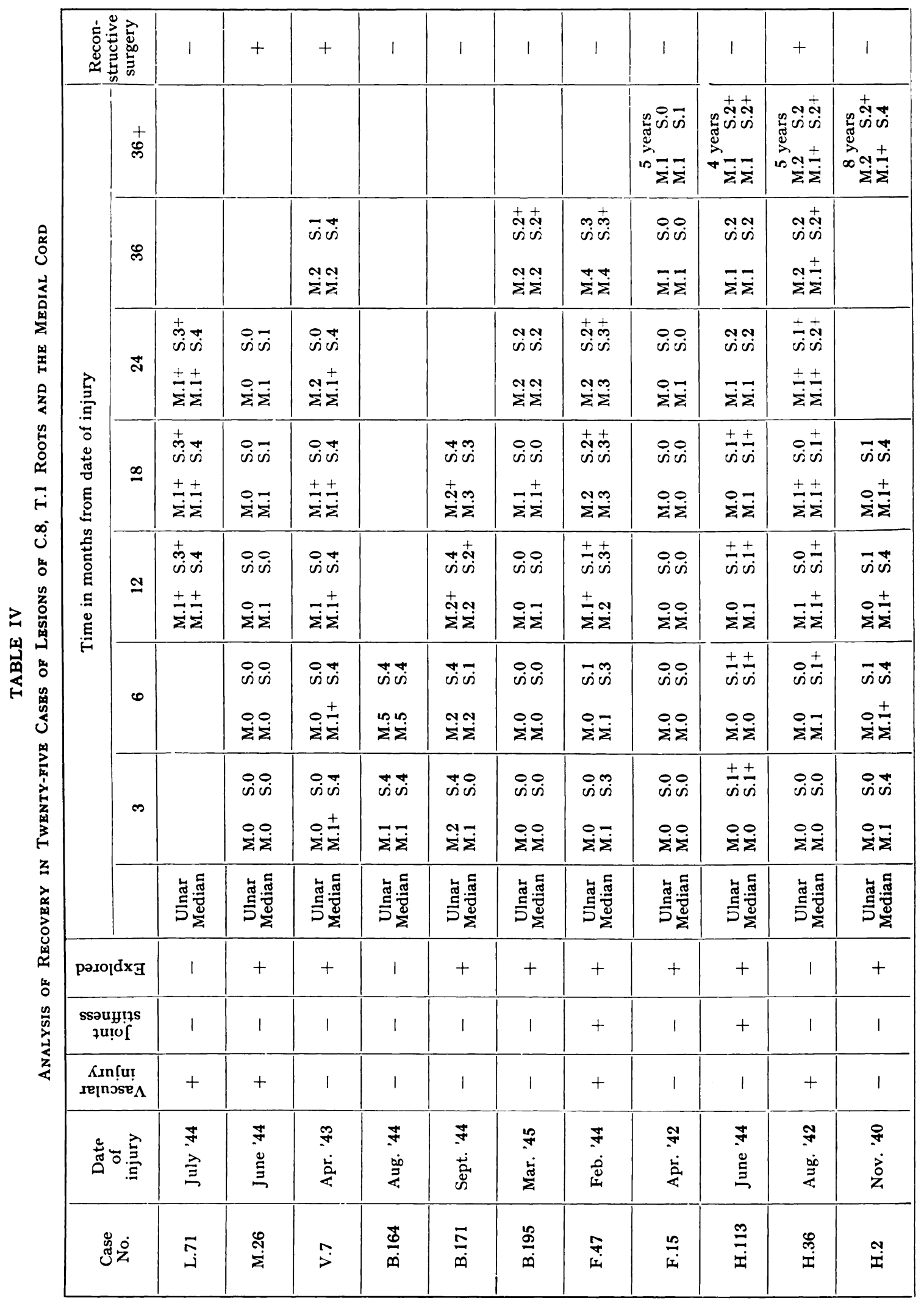


OPEN WOUNDS OF THE BRACHIAL PLEXUS

\begin{tabular}{|c|c|c|c|c|c|c|c|c|c|c|c|c|c|}
\hline 1 & 1 & 1 & 1 & + & $\dashv$ & $!$ & 1 & 1 & + & 1 & + & + & + \\
\hline & & 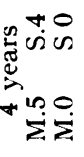 & & 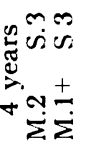 & & & 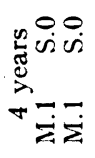 & 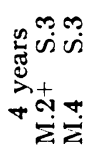 & 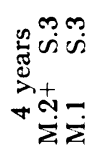 & 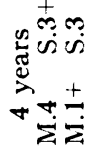 & & 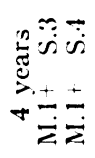 & 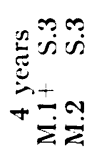 \\
\hline 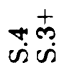 & $\begin{array}{l}\forall \\
\dot{w}\end{array}$ & $\begin{array}{l}+0 \\
\dot{s i v}\end{array}$ & & $\begin{array}{l}\text { cle } \\
\text { vivis }\end{array}$ & $\begin{array}{l}\text { ma } \\
\dot{\omega}\end{array}$ & & $\begin{array}{l}0 \\
\dot{v i v}\end{array}$ & $\stackrel{m}{\infty}$ & 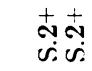 & $\begin{array}{c}m \\
m \\
\dot{m}\end{array}$ & & $\begin{array}{l}\text { vit } \\
\text { vid }\end{array}$ & 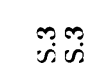 \\
\hline 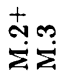 & 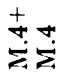 & ن. & & 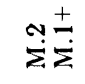 & $\stackrel{+}{\stackrel{+}{*} N}$ & & $\overrightarrow{\dot{\Sigma}} \overrightarrow{\dot{\Sigma}}$ & 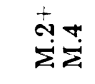 & 产 & $\sum_{\Sigma}^{+}$ & & $\begin{array}{l} \pm \pm \\
\dot{z}=\end{array}$ & تِ \\
\hline 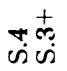 & $\begin{array}{l}\vec{m} \\
\dot{\sim} \dot{\omega}\end{array}$ & 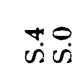 & $\begin{array}{l}\overrightarrow{0} \\
\dot{v} \dot{\omega}\end{array}$ & $\frac{ \pm}{\dot{s}} \frac{ \pm}{\dot{s}}$ & $\begin{array}{l}\text { Nै } \\
\dot{v} v\end{array}$ & 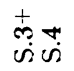 & $\begin{array}{l}\circ \\
\dot{1}\end{array}$ & $\begin{array}{l}m \\
\dot{m}\end{array}$ & 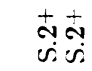 & $\begin{array}{l}+ \\
m \\
\infty \\
\infty\end{array}$ & & 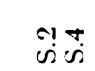 & $\begin{array}{l}\infty \\
\dot{m}\end{array}$ \\
\hline 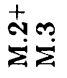 & $\begin{array}{l}+\infty \\
\underbrace{+}_{i}\end{array}$ & : & 䔽 & $\frac{N}{\sum \pm}$ & 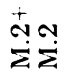 & 茫 & $\overrightarrow{\bar{\lambda}} \overline{\bar{z}}$ & Nִ & 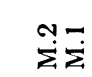 & $\sum_{i}^{\infty} \frac{ \pm}{\Sigma}$ & & $\begin{array}{l} \pm \pm \\
\dot{z} \bar{z}\end{array}$ & \\
\hline $\begin{array}{l}+ \\
\dot{m} \\
\dot{\omega}\end{array}$ & $\begin{array}{l}+ \\
\dot{v} \\
\dot{s}\end{array}$ & $\begin{array}{l}\overrightarrow{0} \\
\dot{v} \dot{s}\end{array}$ & $\begin{array}{l}-\underset{m}{+} \\
\dot{\omega} \omega\end{array}$ & $\begin{array}{l}\dot{v} \\
\dot{v i v}\end{array}$ & $\begin{array}{l} \pm+ \\
\dot{v} \\
\dot{v}\end{array}$ & $\begin{array}{l}\text { के } \\
\dot{m} \vec{v}\end{array}$ & $\begin{array}{l}\dot{0} \\
\dot{v i v}\end{array}$ & 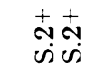 & $\overrightarrow{\dot{v}} \overrightarrow{\dot{s}}$ & $\begin{array}{l}+ \\
\text { mp } \\
\dot{\omega} \omega\end{array}$ & $\ddot{s} \dot{s}$ & $\vec{v} \dot{s}$ & 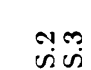 \\
\hline $\begin{array}{l}\stackrel{+}{*} \infty \\
\Sigma \\
\Sigma\end{array}$ & 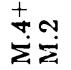 & 京安 & 茫 & $\begin{array}{l} \pm \pm \\
\dot{z}\end{array}$ & $\begin{array}{l} \pm \\
\dot{z}\end{array}$ & $\begin{array}{l}\stackrel{+}{M} T \\
\dot{\Sigma} \\
\end{array}$ & 官完 & تָ & 言可 & 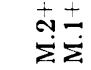 & 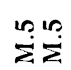 & $\frac{1}{z}$ & 完䚄 \\
\hline 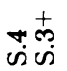 & $\begin{array}{l}\text { vio } \\
\text { vivis }\end{array}$ & $\begin{array}{l}\vec{\theta} \dot{\theta} \\
\dot{\theta} \dot{\theta}\end{array}$ & $\begin{array}{l}+\underset{m}{+} \\
\dot{\omega} \dot{s}\end{array}$ & $\begin{array}{l}\dot{\theta} \\
\dot{v} \dot{\varphi}\end{array}$ & $\begin{array}{l} \pm \pm \\
\dot{v} \dot{s}\end{array}$ & & $\begin{array}{l}\dot{\theta} \\
\dot{\omega} \dot{\omega}\end{array}$ & 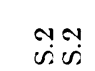 & $\begin{array}{l}00 \\
\text { vivis }\end{array}$ & 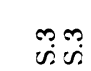 & $\vec{s} \dot{s}$ & $\begin{array}{l} \pm \\
\dot{s} \dot{s}\end{array}$ & $\begin{array}{l}\stackrel{+}{+} \\
\text { siv }\end{array}$ \\
\hline 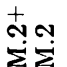 & ${ }_{i=}^{+ \pm}$ & 茫完 & 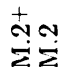 & $\bar{z}$ & $\bar{E}$ & & 일 & $\bar{Z}$ & $=$ & 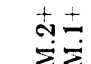 & 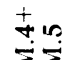 & \pm \pm & 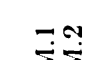 \\
\hline 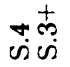 & $\begin{array}{l}\text { ro } \\
\text { vivi. }\end{array}$ & & $\begin{array}{l}+\infty \\
\dot{m} \\
\dot{m}\end{array}$ & $\begin{array}{l}\dot{0} \\
\dot{w} \dot{\omega}\end{array}$ & $\overrightarrow{\dot{s}} \overrightarrow{\dot{s}}$ & & $\begin{array}{l}0 \\
\dot{s i n}\end{array}$ & $\overrightarrow{\dot{s}} \frac{ \pm}{\dot{s}}$ & $\begin{array}{l}\dot{0} \\
\dot{s i s}\end{array}$ & $\begin{array}{l}m \\
\dot{w} \\
\dot{w}\end{array}$ & $\ddot{v \dot{s}}$ & $\overrightarrow{\dot{s}} \overrightarrow{\dot{s}}$ & $=\bar{x}$ \\
\hline 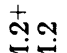 & ז0 & & 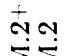 & : & 욱. & & : & $=$ & $\circ$ & $\stackrel{\text { S. }}{=}$ & व̃. & $\Xi \Xi$ & Oִ \\
\hline$\sum \Sigma$ & $\sum \dot{\Sigma}$ & & $\dot{z} \dot{\Sigma}$ & $\dot{\Sigma} \dot{\Sigma}$ & $\dot{z} \bar{z}$ & & $\dot{\Sigma} \dot{\Sigma}$ & $\dot{\Sigma} \dot{\Sigma}$ & $\dot{z} \dot{z}$ & $\dot{\Sigma} \bar{\Sigma}$ & $\dot{\bar{z}} \dot{\bar{z}}$ & $\dot{\bar{z}} \dot{\bar{z}}$ & $\dot{\bar{z}} \dot{\bar{z}}$ \\
\hline 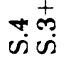 & $\begin{array}{l}\vec{H} \dot{0} \\
\dot{\omega}\end{array}$ & & অُ & & & & $\dot{\phi} \dot{\phi}$ & $\overrightarrow{\dot{s}} \overrightarrow{\dot{s}}$ & & 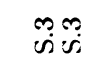 & $\begin{array}{l}+\bar{s} \\
\dot{s}\end{array}$ & & $\dot{0}$ \\
\hline 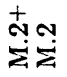 & 莫 & & $\begin{array}{l}\text { No } \\
\dot{\Sigma}\end{array}$ & & & & ن & 定 & & 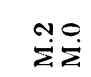 & $\stackrel{N}{\sum}$ & & $\frac{\partial}{\dot{z}}$ \\
\hline 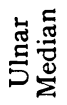 & 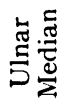 & 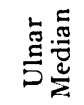 & 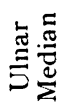 & 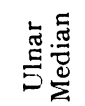 & 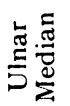 & 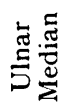 & 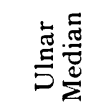 & 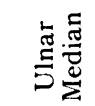 & 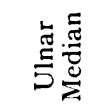 & 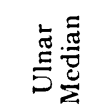 & 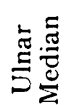 & 䞤胥 & 莺苟 \\
\hline 1 & + & + & + & 1 & + & 1 & 1 & + & + & I & + & + & + \\
\hline 1 & 1 & I & + & + & + & 1 & 1 & 1 & 1 & + & 1 & I & I \\
\hline 1 & + & I & + & + & + & 1 & 1 & 1 & 1 & + & 1 & 1 & + \\
\hline$\exists$ & $\bar{\sigma}$ & $\overline{7}$ & 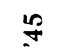 & 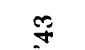 & $\frac{7}{7}$ & 93 & $\dddot{9}$ & $\%$ & $\dddot{m}$ & 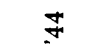 & 8 & $\mathscr{q}$ & 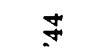 \\
\hline$\stackrel{\vec{\sigma}}{\bar{\Sigma}}$ & $\stackrel{\mathscr{\Xi}}{\Xi}$ & $\stackrel{\lambda}{\Xi}$ & 这 & 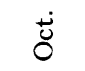 & نें & $\stackrel{\dot{J}}{\sum_{厶}}$ & 灾 & $\begin{array}{l}\text { कें } \\
\ddot{n}\end{array}$ & 完 & $\stackrel{\mathscr{\Xi}}{\Xi}$ & $\dot{\vec{D}}$ & $\stackrel{\dot{0} 0}{\vec{z}}$ & $\stackrel{\mathscr{\Xi}}{\Xi}$ \\
\hline$\underset{\vdots}{\stackrel{\Xi}{\mid}}$ & $\tilde{x}$ & $\begin{array}{l}\infty \\
\dot{x}\end{array}$ & ְִ & 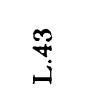 & $\stackrel{\Xi}{\bar{\Sigma}}$ & 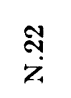 & 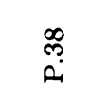 & مُ & 甬 & $\frac{\mathscr{P}}{\dot{s}}$ & $\begin{array}{l}x \\
\stackrel{x}{b} \\
\dot{\omega}\end{array}$ & $\frac{\vec{d}}{\dot{s}}$ & 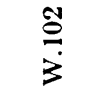 \\
\hline
\end{tabular}




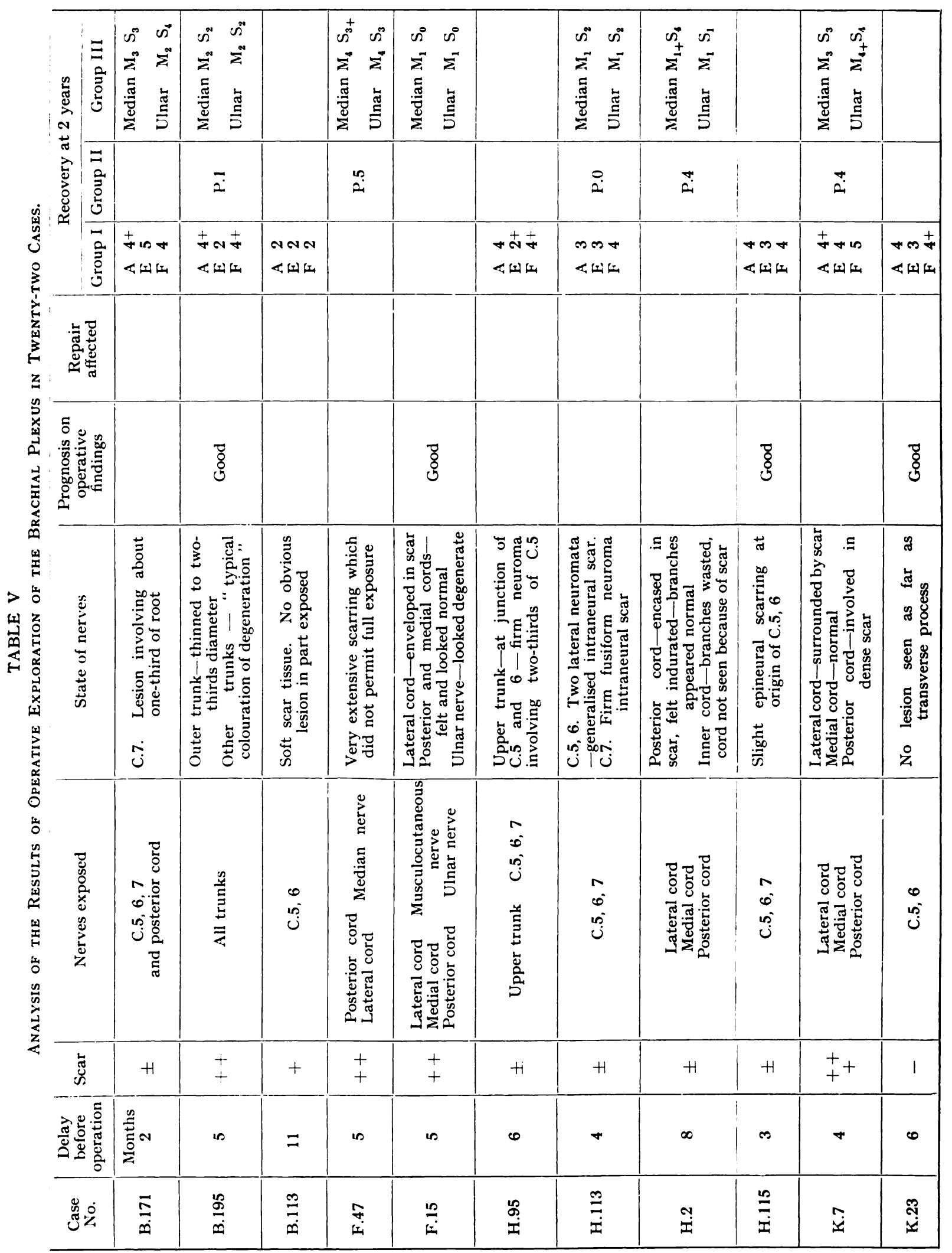

THE JOURNAL OF BONE AND JOINT SURGERY 
OPEN WOUNDS OF THE BRACHIAL PLEXUS

31

\begin{tabular}{|c|c|c|c|c|c|c|c|c|c|c|}
\hline 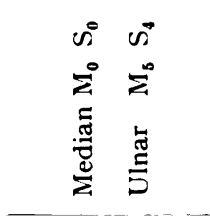 & 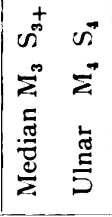 & 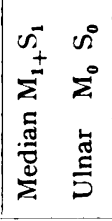 & 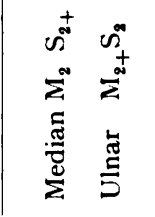 & 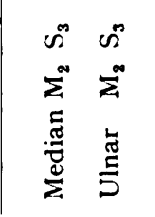 & 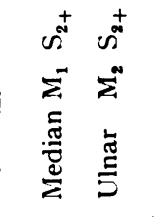 & 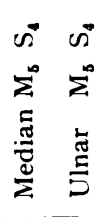 & 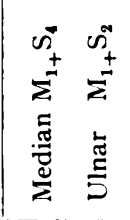 & 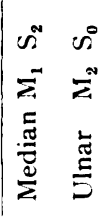 & \multirow[b]{3}{*}{ 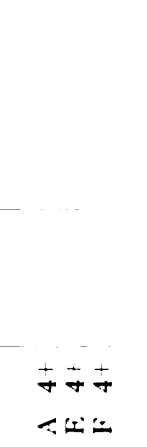 } & 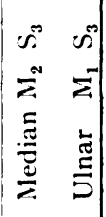 \\
\hline $\bar{a}$ & $\stackrel{+}{=}$ & $\stackrel{\infty}{2}$ & $\bar{\Xi}$ & 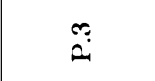 & $\stackrel{+}{\square}$ & 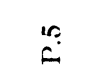 & $\stackrel{+}{\Delta}$ & & & $\stackrel{m}{=}$ \\
\hline $\begin{array}{l}\text { NoO } \\
\text { ४山L }\end{array}$ & & & 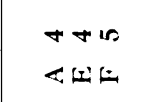 & 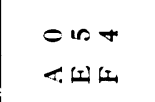 & & $\begin{array}{l}\text { NOO } \\
\text { षinl }\end{array}$ & & & & $\left|\begin{array}{lll}\operatorname{cin} & \multicolumn{1}{l}{\mid}\end{array}\right|$ \\
\hline & & & & & 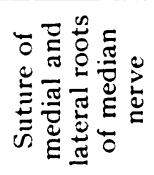 & 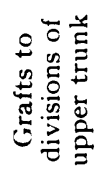 & & & & 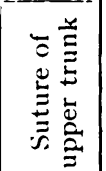 \\
\hline 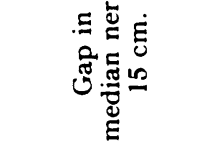 & & & 总 & $\begin{array}{l}\bar{\delta} \\
8 \\
0\end{array}$ & & & 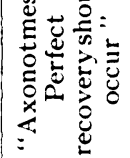 & & & \\
\hline 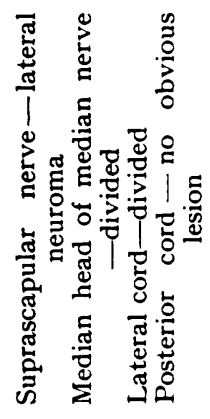 & 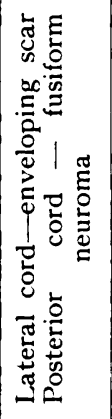 & 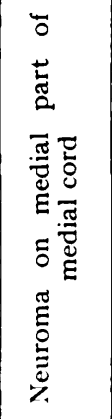 & 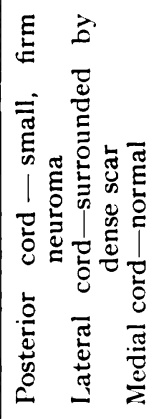 & 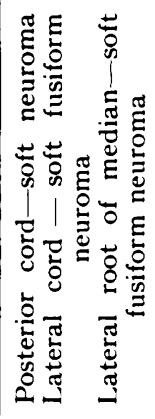 & 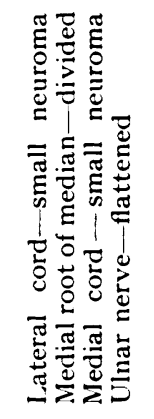 & 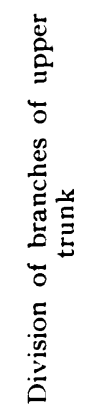 & 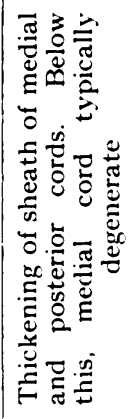 & 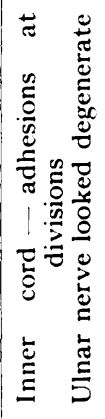 & 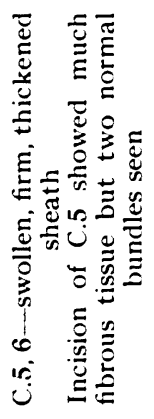 & 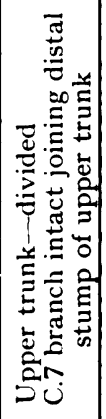 \\
\hline 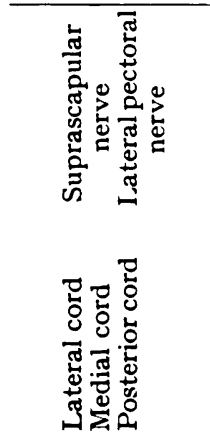 & 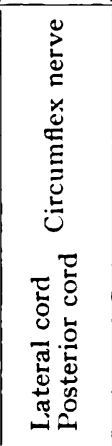 & 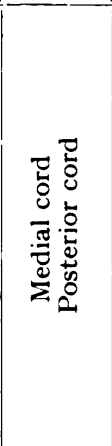 & 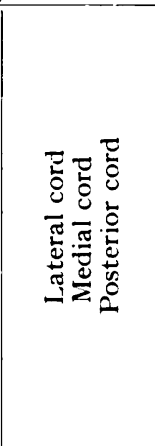 & 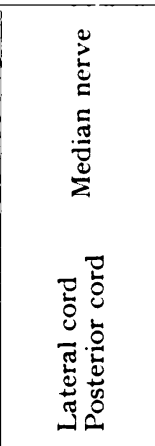 & 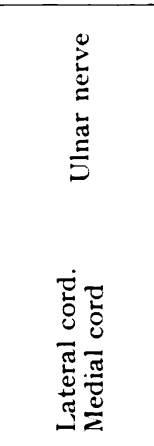 & 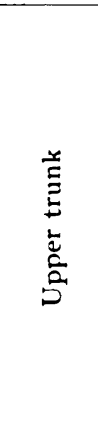 & 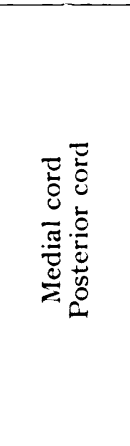 & 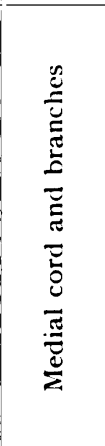 & : & 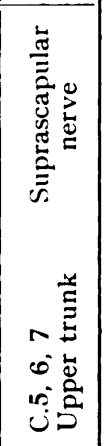 \\
\hline $\begin{array}{l}+ \\
+\end{array}$ & $\begin{array}{l}+ \\
+\end{array}$ & + & $H$ & $\begin{array}{l}+ \\
+\end{array}$ & H & $H$ & 1 & $H$ & + & + \\
\hline$\cong$ & in & $=$ & is & + & 0 & N & $\sigma$ & $\vec{\sigma}$ & - & + \\
\hline ن & : & 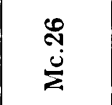 & $\begin{array}{l}\bar{\Xi} \\
\overline{\bar{z}}\end{array}$ & : & $\stackrel{+}{2}$ & $\begin{array}{l}\text { 曋 } \\
\text { in }\end{array}$ & $\begin{array}{l}\stackrel{0}{s} \\
\dot{s}\end{array}$ & $=$ & $=$ & $\frac{0}{3}$ \\
\hline
\end{tabular}

VOL. 31 B, NO. 1, FEBRUARY 1949 
than two years many patients adopted a one-armed way of life so that, even with good proximal recovery in the injured limb, little use was made of it. Close questioning of the twenty-five patients in this group revealed that eighteen did not use the limb at all for finer work such as writing, using a knife and fork, doing up buttons, or opening doors; and one patient summarised his use of the limb as " an emergency paper-weight." Of the other seven cases, four found that the limb was useful in everyday life, and three were equivocal.

Paralysis with injury to a main vesse - In eleven cases, a main artery or vein was found to be damaged either at the time of primary wound excision or at subsequent exploration. The vessels involved were: subclavian artery, 1; axillary artery, 5; brachial artery, 1 ; subclavian vein, 2 ; axillary vein, 2 . In four, the arterial lesion was revealed by the appearance of an aneurism some time after the original wound had healed. In three, the artery was ligated at the time of primary wound excision. With one exception, venous damage was noted at the time of wounding. In one, ligation of the third part of the axillary vein and artery was performed at the primary operation.

The most striking complication which was common to all these cases was joint stiffness, particularly in the hand. In only one case was there evidence of ischaemic damage to muscle or nerve (F.15, Table IV). At the time of primary wound excision the axillary artery and vein were seen and found to be undamaged; the radial pulse was normal. Twenty-four hours later, arterial spasm developed with disappearance of the radial pulse. Injection of novocain into the stellate ganglion gave rise to some improvement in the peripheral circulation but was soon followed by gangrene of the terminal phalanges of the index, middle, and fifth fingers. The plexus was explored five months after injury and no lesion was found, apart from scarring round the nerves. Recovery was poor, and five years after injury the fourth and fifth digits were amputated through the metacarpo-phalangeal joints. At operation the digital vessels were found to be patent and of normal appearance, but the nerves were thin and translucent.

Horner's syndrome-Five cases showed a typical Horner's syndrome either immediately after injury or some weeks later. Two, which were associated with an aneurism, did not develop the syndrome until some time after injury and in neither case did treatment of the aneurism cause disappearance of the well-known signs. The third and fourth cases were of interest. In both, the damage involved mainly the upper trunk and there was little disturbance of the rest of the plexus. One was due to a close range blow-back from a field gun; Horner's syndrome persisted for some weeks, but when examined six months later it had disappeared and tests showed almost normal sweating throughout the limb and face. In the other, even three months after injury, there was complete anhydrosis of the left upper limb and half the face, but with little sensory disturbance. In the fifth case, it was found at operation that there was fracture of the first and second ribs with perforation of the dome of the pleura and lung. The neurological findings were those of a complete lesion of the entire plexus.

The two examples of Horner's syndrome with aneurism were notable in so far as sweating loss was by no means complete in the upper limb; and although pressure effects of the aneurism were removed the signs did not disappear, thus not conforming to the peculiar regenerative properties often attributed to the sympathetic nervous system. In the next two cases it is difficult to imagine how a missile which must have passed very wide of the stellate ganglion could have produced such a syndrome, except by the concussive effect demonstrated experimentally in high velocity missile wounds by Davis et al. (1947). Such explanation is supported by rapid disappearance of the syndrome in one of them. In the final case, it seems probable that fractures of the first and second ribs caused secondary injury of the stellate ganglion. Clinical observations in these patients suggest that the appearance of Horner's syndrome after novocaine block of the stellate ganglion does not necessarily prove that all sympathetic fibres to the limb have been physiologically interrupted. 


\section{SUMMARY}

1. In the first 1600 of the series of peripheral nerve injuries treated during the years $1940-45$ at the Peripheral Nerve Injuries Unit, Oxford, 52 per cent. were due to penetrating wounds, and 6 per cent. of these involved the brachial plexus.

2. A specific method of grouping and grading recovery is described: Group I-lesions of the roots and trunk of C.5, 6; Group II-lesions of the posterior cord; Group III-lesions of C.8, T.1, and the medial cord.

3. The recovery of cases in Group I was good, in Group II fair, and in Group III poor.

4. The brachial plexus was explored on twenty-two occasions. Only in four instances was there interruption of continuity-which is in striking contrast with the frequency in more distal degenerative nerve lesions in open wounds.

5. There is no evidence to suggest that neurolysis influenced motor or sensory recovery, but on one occasion it relieved persistent pain in the limb. In general the correlation between operative findings and prognosis was not precise.

6. With one exception, no recovery of consequence took place in the small muscles of the hand after a lesion in continuity, although galvanic stimulation to all paralysed muscles had been given regularly.

7. There is evidence to suggest that innervation of the biceps may not always be limited to C.5 and 6 and that in a proportion of cases C.7 may make a substantial contribution.

8. In five cases (12 per cent.) Horner's syndrome was present; the causation is discussed.

9. In every case of damage to a main vessel there was a marked tendency to joint stiffness, particularly in the hand, but on one occasion only was there evidence of ischaemic changes in the muscles and nerves.

10. The good spontaneous recovery which occurred in Groups I and II; the poor recovery in Group III even in cases where there was an apparently favourable lesion in continuity; the rarity with which division of nerves was found at operation; and the discouraging results of repair in three cases; make it necessary to conclude that routine exploration of open wounds of the brachial plexus is neither profitable nor justifiable.

I am most grateful to Mr H. J. Seddon for constant encouragement and invaluable advice.

\section{REFERENCES}

Bowden, R. E. M., and Gutmann, E. (1944): Brain, 67, 273.

Davis, L., Martin, J., and Perret, G. (1947): Annals of Surgery, 125, 647.

Ferron, J. (1919): Bulletin et Mémoires de la Société de Chirurgie de Paris, 45, 1603.

Gutmann, E., and Guttmann, L. (1942): Lancet, 1, 169.

Gutmann, E., and Young, J. Z. (1944): Journal of Anatomy, 78, 15.

Holmes, W., and Young, J. Z. (1942): Journal of Anatomy, 77, 63.

JACKsON, E. C. S. (1945): Brain, 68, 300.

LehmanN, W. (1921): Die Chirurgie der peripheren Nervenverletzungen. Berlin: Urban und Schwarzenberg. Medical Research Council. (1920: Reprinted 1924): Special Report Series, No. 54. “Diagnosis and Treatment of Peripheral Nerve Injuries," No. 57.

OpPENheim, H. (1923): Lehrbuch der Nervenkrankheiten. Berlin: S. Karger. Edition 7.

Platr, H. (1924): in Modern Operative Surgery. Edited H. W. Carson. London: Cassell \& Co.

Pollock, L. J. (1926): Surgery, Gynecology and Obstetrics, 43, 415.

Pollock, L. J., and Davis, L. (1933): Peripheral Nerve Injuries. New York: Paul B. Hoeber Inc.

SCAGLietti; O. (1942): Zentralblatt für Neurochirurgie, 7, 129.

SEdDon, H. J. (1943): Brain, 66, 237.

SEDDON, H. J. (1948): British Journal of Surgery, Supplement, Wounds of the Extremities.

Simpson, S. A., and Young, J. Z. (1945): Journal of Anatomy, 79, 63.

Stiles, H. J., and Forrester-Brown, M. F. (1922): Treatment of Injuries of the Peripheral Spinal Nerves. Oxford Medical Publications. London: Henry Frowde and Hodder \& Stoughton. 